\title{
KONFLIK AGRARIA ANTARA MASYARAKAT DENGAN \\ PERUSAHAAN PEMEGANG HPHTI \\ DI KABUPATEN PELALAWAN
}

Sobri, S.IP, MA

\begin{abstract}
Agrarian conflict between the people living in the villages of the pelalawan district is due to the change of government policy related to the pattern of management of natural resources such as forest, land and river, from "subsistence" pattern to the pattern of industrialization in the forestry sector becoming the root of agrarian conflict in Riau province. The change of development policy from the pattern of Subsistence to the pattern of industrialization in the forestry and plantation sectors created by the government led to changes in the control of natural resources such as land, rivers and forests from the "Subsistence" pattern based on ulayat concept, to become widespread land tenure (monopoly) by the owners of capital (the corporations).
\end{abstract}

\section{Keywords; Agrarian Conflict}

\section{Pendahuluan}

Konflik yang terkait dengan
pemanfaatan fungsi tanah antara
masyarakat dengan perusahan yang
mengembangkan usahanya disektor
perkebunan dan kehutanan di indonesia
menjadi sejarah kelam yang panjang
dalam hubungan antara masyarakat
khususnya kaum petani dengan kalangan industri pemilik HPHTI dan HGU. Ketersediaan sumber alaiah seperti tanah, hutan dan sungai dengan segala fungsinya dalam sistem sosial-ekonomi masyarakat agraris berfungsi sebagai urat nadi kehidupan bagi yang berada dikampung-kampung diseluruh pelosok indonesia kaum petani. Kekayaan sumber ekonomi alamiah ini tidak saja memiliki nilai ekonomis sebagai jaminan keberlangsungan kehidupan masyarakat agraris yang hidup di kampongkampung, tetapi juga punya makna dan nilai budaya dan religius (kearifan lokal) bagi masyarakat yang menjadikannya sebagai sumber kehidupan.

Namun sayangnya Negara yang semestinya hadir untuk memberi jaminan akan keberlangsungan kehidupan bermasyarakat itu ternyata hingga saat ini belum mampu menjalankan tujuan dan fungsinya sebagai sebuah Negara sesuai dengan 
amanah Undang-Undang Dasar yang tertuang dalam pembukaan tercantum dalam dalam pembukaan UUD 1945 alinea ke empat yang menyatakan;

“Membentuk suatu pemerintah negara

Indonesia yang melindungi segenap

bangsa Indonesia dan seluruh tumpah darah Indonesia dan memajukan

kesejahteraan umum, mencerdaskan

kehidupan bangsa, dan ikut serta melaksanakan ketertiban dunia berdasarkan kemerdekaan, perdamaian abadi dan keadilan sosial”. Negara yang seharusnya menjalankan fungsinya untuk mengatur mekanisme pengelolaan dan penguasaan terhadap tanah, hutan dan sungai serta segala potensi yang terkandung didalamnya sebagai sumber daya alam yang berkorelasi langsung dengan keberlangsungan kehidupan masyarakat di kampong-kampung diseluruh pelosok ibu pertiwi ini dengan model system social-ekonomi dan politik agraris ini. Namun sayangnya, kebijakan terdahulu Negara dibidang industrialisasi sektor perkebunan dan kehutanan di Indonesia yang bercorak “kapitalistik”, ditengarai menjadi akar persoalan munculnya fenomena konfik agraria antara masyarakat tempatan perusahaan yang memiliki HPHTI dan HGU dibanyak kawasan di Indonesia.

Fenomena ini menjadi indikasi kegagalan Negara dalam mengelola, mengatur dan mendistribusikan secara adil potensi sumber daya alam karunia tuhan yang melimpah ditengah-tengah masyarakat, hingga ahirnya menjadi akar penyebababkan terjadinya berbagai rentetan konflik disektor agraria ini hampir diseluruh Provinsi dan Kabupaten di Indonesia.

\section{Industrialisasi Disektor Pertanahan Di}

\section{Kabupaten Pelalawan}

Kabupaten Pelalawan adalah sebagai salah satu kawasan yang mengalami proses industrialisasi di sektor hutan tanaman industri (HTI) di provinsi Riau. Di kabupaten ini Terdapat dua kawasan Hak Penguasaan Hutan Tanaman Industri (HPHTI) Pulp And Paper terbesar di Asia, dibawah anak perusahaan PT. Asia Pacific Resources International Holdings Ltd (APRIL RROUP) dan PT. Indah Kiat Pulp And Paper (IKPP Tbk) ditambah lagi dengan Hak Guna Usaha (HGU) berbagai perusahaan perkebunan kelapa sawit juga berada dikawasan Kabupaten ini.

Luas Kabupaten Pelalawan 1.382.210.08 Ha, terdiri dari wilayah 
daratan selauas 1.315.579.44, wilayah laut seluas 66.630.64, luas kawasan hutan berdasarkan RTRW tahun 20012015 selauas 755. 846.10 На. Berdasarkan data Laporan Akhir Kajian Iventarisasi Potensi Sumber Daya Alam di Kabupaten Pelalawan Tahun ( 2009), luas perkebunan Kelapa Sawit yang memiliki HGU sebanyak 307.550.62 Ha, dan luas perkebunan Hutan Tanaman Industri (HTI) berdasarkan HPHTI seluas 429.070.97 Ha, Penggunaan lahan di Kabupaten Pelalawan pada umumnya didominasi oleh hutan tanaman industri (akasia) yaitu mencakup luasan 35\% dan perkebunan kelapa sawit (muda dan tua) yaitu mencakup luasan 25\% luas wilayah Kabupaten Pelalawan, sisanya berupa hutan rawa, hutan rawa gambut, hutan pasang surut, perkebunan rakyat, semak belukar, dan pemukiman. Jumlah perusahaan yang bergerak di sektor hutan tanaman industri (HTI) sebanyak 40 perusahaan, kesemua perusahan HTI ini berada dibawah naungan induk perusahaan PT. Asia Pacific Resources International Holdings Ltd (APRIL RROUP) dan PT. Indah Kiat Pulp And Paper (IKPP Tbk), Penguasaan terluas lahan HTI di Kabupaten Pelalawan dimiliki oleh PT.Riau Andalan Pulp \&
Paper seluas 14.718.707 Ha, dan PT. Arara Abadi seluas 10.363.110 Ha.

Sejalan dengan terjadinya pertumbuhan disektor industrialisasi perkebunan dan kehutanan di Kabupaten ini sejak sebelum menjadi kabupaten pemekaran (dahulunya Kabupaten Kampar, dimekarkan menjadi Kabupaten Pelalawan tahun1999). Proses industrialisasi disektor kehutanan dan perkebunan sejak tahun 1990-an di Kabupaten pelalawan ini tentunya telah membawa dampak positif dalam bidang ekonomi dan lapangan pekerjaan pormal dikawasan ini. Namun di sisi lainnya, bersamaan dengan lajunya pertumbuhan industrialisasi tersebut juga telah membawa dampak lain seperti perubahan kawasan, dari kawasan hutan alam menjadi kawasan industri perkebunan, berkurangnya jumlah sungai-sungai kecil sebagai akibat perubahan kawasan hutan dan semakin menyusutnya lahan untuk pertanian bagi masyarakat tempatan.

Sejak 20-an tahun terahir, kawasan ini juga tidak luput dari berbagai kasus konflik dan kekerasan antara masyarakat dan perusahan pemegang izin HGU dan HPHTI menyangkut klaim atas penguasaaan dan pengelolaan lahan. Adanya konflik 
pengunaan lahan antara masyarakat dengan perusahan pemegang HGU dan HPHTI di wilayah ini menunjukkan bahawa potensi alam karunia tuhan yang ada kawasan ini tidak terdistribusikan dengan adil dan merata. Potensi sumber daya alam yang melimpah sebagai penyumbang devisa Negara dan penyumbang PAD daerah belum mampu diatur dan dikelola untuk meningkatkan kesejahteraan dan memberikan rasa aman bagi masyarakat lokal (tempatan) di kabupaten Pelalawan.

\section{Kondisi Sosial Dan Ekonomi} Masyarakat Pelalawan

Masyarakat tempatan yang tinggal di Kabupaten Pelalawan adalah masyarakat suku Bangsa Melayu, sebagaimana umumnya suku bangsa melayu di Indonesia suku bangsa ini memiliki sistem nilai lokal yang berfungsi sebagai panduan dalam bertingkah laku dalam hubungan sosial dengan masyarakat dan lingkungan tempat tinggalnya. Sistem nilai yang wujud dalam masyarakat ini akan membantu proses pendefinisian terhadap norma, adat istiadat dan tradisi yang mereka miliki. Sistem nilai ini berasal dari wariaan budaya leluhur mereka, dikalangan masyarakat Melayu ia dikenal sebagai adat istiadat, tradisi dan resam. Selain dari warisa leluhur, sistem nilai dalam masyarakat Melayu juga sebagiannya berasal dari penyerapan nilai budaya dari luar yang disesuaikan dengan sifat dan suasana kehidupan anggota masyarakat setempat. Selain berfungsi sebagai falsafah kehidupan sistem nilai budaya ini menjadi identitas kelompk masyarakat masyarakat melayu di kawasan ini. Sistem nilai ini sangat besar peran dan berfungsinya untuk mengatur tingkah laku anggota masyarakat supaya anggota masyarakat tidak kehilangan orientasi kehidupan dan seterusnya menjadi acuan dalam setiap tindakan laku, sehingga membolehkan berjalannya suatu hubungan sosial antara sesama masyarakat juga antara anggota masyarakat dengan lingkungan sekitarnya.

Menurut UU Hamidi (1982), terdapat sekurang-kurangnya tiga sistem nilai yang sentiasa dijaga dan diamalkan dalam kehidupan harian masyarakat Melayu di Riau.

Pertama, terdapat sistem nilai yang berasal dari ajaran agama. Bagi masyarakat Pelalawan, nilai yang terkandung dalam ajaran agama Islam dipandang sebagai sistem nilai yang 
utama jika dibandingkan dengan sistem nilai yang lain. Oleh kerana itu jika terdapat individu yang taat mengikuti dan mematuhi ajaran dalam nilai agama tersebut dia dipandang sebagai manusia yang memiliki martabat yang tinggi, dan seterusnya dia sentiasa akan menjadi tauladan dan panduan bagi masyarakat awam.

Kedua, sistem nilai yang didapati dalam adat istiadat. Sistem nilai ini berfungsi sebagai standar ukuran dan ketentuan terhadap bagaimana individu dan kelompok di dalam sesebuah masyarakat berkelakuan. Sistem nilai ini dibuat berdasarkan pemikiran yang mendalam dari pemimpin adat terdahulu tentang bagaimana sebaiknya kehidupan masyarakat dapat diuruskan dan seterusnya berguna bagi mengatur hubungan sesama anggota masyarakat sehingga kehidupan boleh berjalan dengan damai. Sistem nilai ini dibuat bersama-sama dengan hukuman yang tegas bagi sesiapa yang melanggarnya dan seterusnya ia menjadi peraturan yang mengatur hubungan antara individu dengan individu atau kelompok lain dan antara pemimpin dengan masyarakat yang dipimpinnya.
Ketiga, sistem nilai yang berasal dari sebuah tradisi. Sistem nilai ini berfungsi untuk membuat hubungan harmoni antara manusia dengan alam sekitarya. Jika sistem nilai agama bersumberkan dari wahyu dari Tuhan dan sistem nilai adat berdasarkan pemikiran pemimpin adat terdahulu sistem nilai tradisi pula bersumberkan mitos. Uraian tentang ketiga sistem nilai ini merupakan suatu realitas sosial dan budaya yang masih berlaku dalam sistem sosial masyarakat Melayu Pelalawan. Masyarakat ini sangat taat berpegang kepada ketentuan adat dan agama, ketiga sistem nilai ini selalu muncul dalam setiap tingkah laku sosial masyarakat, oleh kerana itu setiap aktivitas sosial yang masyarakat lakukan tidak pernah terlepas dari salah satu sistem nilai ini.

Pertama, adat sebenar adat yang juga digelar sebagai adat yang sebenar, yaitu suatu peraturan nilai yang datang dari. Allah yang berlaku terhadap seluruh alam. Sebagian dari nilai ini berada dalam kitab suci, dan sebagian lagi menjadi hukum alam itu sendiri. Kewujudan adat sebenar adat dalam bentuk hukum alam dan syariat tidak dapat di rubah, kerana apabila nilai 
tersebut diabaikan ia boleh Melayu di Riau, sistem nilai adat menyebabkan kehancuran bagi manusia.

Kedua, adat yang diadatkan iaitu nilai dan norma adat yang berasal dari pemikiran manusia dan seterusnya ia berfungsi sebagai acuan dan panduan dalam hubungan antara sesama masyarakat dan alam. Sebagai sistem nilai dan norma yang dibuat oleh manusia ia boleh berubah mengikut keadaan yang berlaku dalam masyarakat. Dalam sistem nilai masyarakat Melayu di Riau sistem nilai ini juga berfungsi mengatur hubungan sosial antara pemimpin dan masyarakat yang dipimpinnya.

Ketiga, adat yang teradat iaitu keputusan mesyuarat adat dan seterusnya dikukuhkan sebagai sistem nilai dalam kehidupan bermasyarakat. Sistem nilai dalam adat yang teradat ini lebih banyak mengatur budi pekerti atau etika berkomunikasi supaya manusia lebih berbudi bahasa.

Keempat, adat istiadat iaitu berbagai ketentuan yang semestinya dilaksanakan dalam kehidupan bermasyarakat. Adat istiadat tidak hanya mengatur hubungan antara sesama manusia, tetapi juga mengatur hubungan manusia dengan alam sekitamya. Bagi masyarakat adat

menjadi panduan dalam kehidupan sehingga membolehkan proses sosial berjalan dengan harmoni antara sesama manusia dan antara manusia dengan lingkungannya.

\section{Sistem Pemanfaatan Lahan Dalam Masyarakat Melayu Pelalawan}

Masyarakat adat Melayu di Riau khususnya di kabupaten Pelalawan, memiliki pola pengaturan mengenai hak dan kedaulatan terhadap alam yang berfungsi sebagai sumber kehidupan dalam masyarakat adat yang disebut sebagai Hak Ulayat. Dalam konsep hak ulayat, adat secara kelembagaan yang diterajui oleh pemangku adat akan mempunyai kuasa ke atas masyarakat adat dan segala kekayaan sumber alamnya. Pola Kedaulatan (penguasaan) ini mengikut aturan adat resam yang telah diwariskan secara turun temurun dalm masyarakat tersebut. Setiap masyarakat adat memiliki sumber ekonomi dan budaya untuk memenuhi keperluan kehidupannya. Oleh itu, mereka memiliki kawasan "Tanah Ulayat" yang meliputi kawasan seperti; hutan, tanah, wilayah perairan dengan segala sumber yang ada didalamnya. 
Konsep tentang ulayat ini dituliskan dengan jelas ole salah seorang cendikiawan riau UU. Hamidi (2006) didalam tulisannya menyatakan bahawa tanah ulayat adalah suatu wilayah yang dimiliki dan dipelihara oleh masyarakat adat sebagai sumber kehidupan untuk kesejahteraan masyarakat seperti (1) Tanah perkarangan (2) Tanah perladangan (3) tanah kebun (4) Hutan kepungan sialang (5) Hutan simpanan (6) Perairan penangkapan ikan (7) Padang pengembalaan (8) Tanah kandang (9) Tanah koto (10) Tanah Perkuburan.

Selanjutnya menurut UU Hamidi (2006) pola pengelolaan dan pemanfaatkan potensi yang ada dalam kawasan ulayat, pemangku adat mengatur wilayah ulayat untuk masyarakat adat. Dalam pola pengaturan ini sekurang-kurangnya terdapat empat pembagian asas berkaitan hutan dan tanah yang menjadi ruang lingkup ulayat :

Pertama, hutan simpan tidak boleh diubah menjadi kebun atau lading, oleh katena itu ia dikenali sebagai hutan larangan. Berbagai sumber ekonomi yang terdapat dalam hutan ini seperti kayu-kayan, rotan, gaharu, damar, buahbuahan hutan, binatang buruan, ikan dan burung boleh diambil dengan syarat ia tidak merusakkan kelestarinnya. Tatacara orang Melayu di Riau menjaga hutan simpanan terkandung dalam sebuah "bidal" yang berbunyi, "kayu ditebang diganti kayu, rimba ditebang diganti rimba".

Pada masa dahulu, jika penduduk tempatan mengambil hasil hutan untuk keperluan makanan dan digunakan setakat untuk memenuhi keperluan harian, pemangku adat tidak akan memungut cukai. Sekiranya hasil hutan tersebut diambil untuk dijual beli, maka ia harus mendapat restu dari pemangku adat dan akan dikenakan cukai.

Kedua, tanah kebun dan ladang, yaitu, tanah yang digunakan oleh masyarakat sebagai tempat menanam padi dan berbagai jenis sayuran, buah-buahan dan padi untuk memenuhi keperluan harian dan selebihnya dijual untuk memenuhi kebutuhan sekuder lainnya.

Ketiga, tanah perkarangan. Tanah ini adalah tempat untuk masyarakat membina rumah atau pemukiman. Biasanya di sekitaran rumah ditanam dengan berbagai tanaman pangan dan obat-obatan, seperti pokok kelapa, pisang, limau, 
jambu, nangka, mangga dan berbagai jenis tanaman obat- obatan.

Empat, hutan kepung sialang, sialang adalah penamaan untuk suatu jenis pohon hutan yang bisa tumbuh sangat besar dan tinggi tempat lebah bersarang. Pohon sialang ini biasa dijumpai tumbuh di dekat sungaisungai ataupun di kawasan hutan lainnya. Hutan ini sengaja dibiarkan tumbuh dan dijaga keberadaannya oleh masyarakat, karena pohon ini tempat lebah hutan membuat sarang supaya madunya boleh diambil untuk kegunaan sendiri ataupun untuk dijual. Dalam masyarakat Melayu lebah hutan disebut sialang dan seterusnya pokok kayu tempat lebah tersebut membuat sarang dinamakan pokok kayu sialang.

Pola pengelolaan kawasan ulayat ini pada masa dahulu, yang meliputu hutan, tanah, dan perairan Melayu Riau telah memberikan kesejahteraan secara sosial-ekonomi kepada penduduk tempatan. Tatacara pengelolaan dan pemanfaatan ulayat ini bukan hanya memberi manfaat secara ekonomi kepada masyarakat tetapi juga memberi ruang hidup kepada hewan dan tumbuhan yang dilindungi oleh negara. Pola-pola pengelolaan lingkungan seperti dilakukan oleh masyarakat Melayu di Riau telah memberi kesempatan kepada semua makhluk yang hidup untuk mendapat tempat untuk hidup secara wajar dalam ruang masyarakat adat Melayu Riau.

Kearifan system nilai dalam adat resam masyarakat melayu di Riau dalam menjaga ulayat tersirat dalam gurindam dan pantun. Tenas Effendi (1994), seorang sasterawan Riau iaitu :

\section{Tunjuk Ajar Orang Melayu}

Kalau hidup hendak selamat.

Pelihara laut dan selat.

Pelihara tanah dan hutan lebat.

Di situlah terkandung rezeki dan rahmat.

Di situlah terkandung tamsil ibarat.

Di situlah terkandung aneka nikmat.

Apabila rosak alam sekitar.

Sempit tidak dapat berlegar.

Goyah tidak dapat bersandar.

Panas tidak dapat mengekas.

Hujan tidak dapat berjalan.

Teduh tidak dapat berkayuh.

Apabila alam sudah binasa,

Bala turun celaka tiba.

Hidup melarat terlunta lunta.

Pergi ke laut malang menimpa.

Pergi ke darat miskin papa. 
Apabila alam menjadi rosak.

Turun temurun hidup kan kemak.

Pergi ke laut ditelan ombak.

Pergi ke darat kepala tersundak.

Hidup susah dada pun sesak.

Periuk terjerang nasi tak masak.

Apabila alam menjadi punah.

Hidup dan mati takkan semengah.

Siang dan malam tertimpa musibah.

Fikiran kusut hati gelabah.

Apabila rosak alam lingkungan,

Di situlah punca kemalangan.

Musibah datang berganti-ganti.

Celaka melanda tak berkesudahan.

Hidup sengsara binasalah badan.

Cacat dan cela jadi langganan.

Hidup dan mati jadi sesalan.

Apabila alam porak poranda.

Di situlah tumbuh silang sengketa.

Aib datang malu menimpa.

Anak cucu hidup sengsara.

Makna yang tersirat dalam gurindam ini menjelaskan bahwa sangat pentingnya pengaturan dan pengelolaan alam sekitar seperti hutan, tanah, sungai dan selat, untuk keberlangsungan kehidupan masyarakat melayu di pelalawan. Ketika masyarakat sudah kehilangan nilai-nilai kearifan lokalnya, sumber kehidapan ini tidak terkelola dan di distribusikan secara adil, maka dalam kehidupan masyarakt akan timbul masalah sosial dalam seperti; kemiskinan, keterpinggiran (marjinal) musibah berupa bencana alam, silang sengketa (konflik).

\section{Kondisi ekonomi}

Masyarakat etnik Melayu yang bertempat tinggal di desa-desa di kabupaten pelalawan pada umumnya menyara hidup dengan pola "Subsistens", dengan bekerja sebagai petani, nelayan sungai dan memelihara hewan bertenak, mengambil madu hutan dan lain-lainnya. Pada intinya, sebagian besarnya masih menganut pola ekonomi Subsistensi (menggantungkan sumber ekonominya kepada ketersediaan sumber daya alam semula jadi) seperti tanah, hutan dan sungai serta segala keaneka ragaman hanyati didalamnya.

Ketersediaan lahan pertanian untuk berladang dan berkebun, serta kelestarian hutan, sungai dan danau adalah kunci utama dalam ketahan pangan dan keberlangsungan ekonomi mereka. Hal ini dapat tergambarkan dari data tanaman pangan yang diterbitkan Oleh BPS kabupaten pelalawan tahun (2012) yang lalu;

Produksi padi di Kabupaten Pelalawan disumbang dari lahan pasang surut dan tadah hujan. Belum ada sistem 
irigasi teknis.Tanaman palawija dengan luas panen terbesar adalah jagung. Selain jagung tanaman palawija lain yang ditanam masyarakat antara lain: ubi kayu, kedelai, ubi jalar, kacang tanah dan talas. Tanaman sayur-sayuran yang biasa ditanam adalah kacang panjang, cabe besar, cabe rawit, terung, ketimun dan kangkung. Sedangkan sektor perkebunan terutama kelapa sawit dan karet memberikan kontribusi yang signifikan terhadap perekonomian Pelalawan. Perkebunan kelapa sawit diusahakan hampir di semua kecamatan di Pelalawan. Tanaman karet juga banyak ditaman oleh masyarakat hampir disemua kecamatan yang ada. Sedangkan disektor peternakan, beberapa jenis hewan ternak yang diusahakan adalah sapi, kerbau, kambing, ayam dan itik.

Disektor perikanan darat, Kabupaten Pelalawan memiliki potensi perikanan yang menjanjikan, terutama perikanan budidaya, hal ini disebabkan karena Kabupaten Pelalawan mempunyai sungai-sungai dengan panjang mencapai 1.821 kmdan luas 34.924 ha. Kampung-kampung masyarakat Melayu dipelalawan pada umumnya berada di tepi-tepi sungaisungai ini, karena mengingat keberadaan sungai sangat penting bagi mereka. Sungai selain berfungsi sebagai tempat mencari ikan, sungai juga dianfaatkan untuk tempat mandi, mencuci, tempat buang hajat (WC). Hingga sampai saat ini sungaipun masih dimanfaatkan sebagai jalur transportasi untuk menganggkut hasil pertanian mastyarakat.

\section{Dinamika Konflik Agraria di}

\section{Kabupaten Pelalawan}

Focus kajian konflik agrarian ini dibatasi pada konflik pemanfaatan lahan antara mastarakat dengan salah satu perusahaa pemegang Hak Pengusaan Hutan Tanaman Industri (HPHTI), salah satu anak perusahan PT. Indah Kiat Pulp And paper (IKPP tbk) yang memiliki kawasan HTI di Kabupaten Pelalawan.

Dikawasan provinsi Riau terdapat dua perusahaan HPHTI yang perusahaan yang beroperasi di bidang Pulp and Paper, yaitu PT. Asia Pacific Resources International Holdings Ltd (APRIL RROUP) dan PT. Indah Kiat Pulp And Paper (IKPP Tbk), kedua perusahan tersebut beserta mitra memiliki kawasan industry di kabupaten pelalawan. Kedua-dua perusahaan HPHTI ini sama-sama meiliki persoalan konflik agrarian dengan masyarakat desa 
disekitar kawasan operasional industry HTI mereka.

Berdasarkan hasil kajian yang telah dilakukan pada tahun 2013-2014 ditenemukan sebanyak 22 desa di kabupaten ini berkonflik terkait dengan Klaim tentang penguasaan dan pengelolaan sektor pertanahan dengan perusahaan tersebut. Desa-desa tersut antra lain adalah; 1) Dusun Tua (Kc. Pangkalan Lesung). 2) Deasa Mak Teduh (Kc. Kerumutan). 3). Lubuk Keranji (Kc. Bandar Petalang). 4). Desa Guha (Kc. Pangkalan Lesung). 5) Desa Lipai Bulan (Kc. Kerumutan). 6) Desa Merbau (Kc. Bunut). 7). Desa Pulau Panduk (Kc. Kerumutan. 8). Desa Tanjung Air Hitam (Kc. Kerumutan). 9). Desa Telayap (Kc. Pelalawan). 10). Desa Sungai Buluh (Kc. Bunut). 11). Desa Kesuma (Kc. Pangkalan Kuras). 12). Desa Betung (Kc. Pangkalan Kuras). 13). Desa Gundai (Kc. Langgam). 14). Desa Pulau Muda (Kc. Teluk Meranti). 15) Desa Balam Merah (Kc. Bunut). 16). Desa Dundangan (Kc. Pangkalan Kuras). 17). Desa Terbangngiang (KC. Bandar Petalang). 18). Desa Segamai (Kc. Teluk Meranti). 19) Desa Gambut Mutiara (Kc. Teluk Meranti). 20). Desa Serapung (Kc. Kuala Kampar) . 21). Desa Lubuk Raja (Bandar Petalang). 22) Desa Tambun (Kc. Bandar Petalang)

\section{Penyebab Konflik}

Konflik pemanpaatan lahan yang terjadi antara perusahaan pemilik HPHTI, di kabupaten pelalawan, pola konflik yang terjadi tidak jauh berbeda dengan konflik pemanfaatan lahan yang terjadi di Provinsi Riau secara umum. Konflik angraria ini terjadi bermula sejak di keluarakannya Surat Keputusan Mentri Kehutanan (SKMK) No. 173/Kpts-II/1986 Tanggal 6 Juni 1986 Tentang Tata Guna Hutan Kesepakatan (TGHK) di kawasan Provinsi Riau. Dasar dari TGHK inilah yang menjadi rujukan pemerintah mengeluarkan Surat Keputusan Menteri Kehutanan No. 743/Kpts-II/1996 tanggal 25 November tahun 1996, Tentang Pemberian Hak Penguasaan Hutan Tanaman Industri Atas Areal Hutan Seluas \pm 299.975 Ha, Kepda PT. Arara Abadi dan perusahaan HTI lainnya di kawasan Provinsi Riau.

Persoalan konflik antara masyarakat dengan perusahaan HTI ini terjadi karena, didalam kawasan yang ditetapkan sebagai kawasan Tata Guna Hutan Kesepakatan (TGHK) oleh pemerintah yang menjadi landasan dikeluarkannya izin HPHTI khususnya HTI milik perusahaan PT. Arara Abadi tersebut, didalamnya terdapat perkampungan penduduk tempatan 
(Desa), kebun masyarakat, kawasan perladangan, sungai, danau, kuburan, hutan sialang, padang pengembalaan masyarakat, situs sejarah yang oleh masyarakat diakui sebagai kawasan ulayat masyarakat adat, yang berfungsi sebagai sember kehidupan yang telah dimukimi, dikelola jauh sebelum dikeluarakannya Surat Keputusan Mentri Kehutanan (SKMK) No. 173/KptsII/1986 Tanggal 6 Juni 1986 Tentang Tata Guna Hutan Kesepakatan (TGHK) dan Surat Keputusan Menteri Kehutanan No. 743/Kpts-II/1996 tanggal 25 November tahun 1996, Tentang Pemberian Hak Penguasaan Hutan Tanaman Industri Atas Areal Hutan Seluas \pm 299.975 Ha, Kepda PT. Arara Abadi dan perusahaan HTI lainnya di kawasan Provinsi Riau.

Sebenarnya permasalah yang menjadi sumber konflik ini sudah diatur secara Hukum seperti, tertuang pada point 4 butir 1 dalam Surat Keputusan Menteri Kehutanan No. 743/KptsII/1996, SK Menteri Kehutanan Kepada PT.Arara Abadi Yang berbunyi “ Apabila di dalam areal HPHTI tersebut terdapat lahan yang menjadi milik, perkampungan, tegalan, persawahan atau telah diduduki dan digarap oleh pihak ketiga, maka lahan tersebut di keluarkan dari areal kerja HPHTI Perusahaan".

Selajutnya, pada poin 4 butir 2 disebutkan; “apabila lahan tersebut ayat 1 (satu) dikehendaki untuk dijadikan areal HPHTI, maka penyelesaian dilakukan oleh Perusahaan pemilik HPHTI dengan pihak-pihak yang bersangkutan sesuai dengan ketentuan peraturan dan perundang undangan yang berlaku”. Namun, hingga sampai saat kajian ini dilakukan tahun 2013, belum ada sebuah penyelesaiyan terkait kasus tumpang tindik kepemilikan lahan antara masyarakat dengan perusahaan pemegang HPHTI tersebut.

Masyarakat yang bermukim di Desa-Desa yang masuk dalam status Kawasan HPHTI perusahaan secara terus menerus menuntut kepada pemerintah tentang jaminan kepastian atas hak-hak mereka, bahkan sudah pernah menyampaikan permasalahan tersebut kepada Pemerintah Pusat (Menteri kehutanan). Masyarakat menuntut jaminan atas hak-hak penguasaan dan pengelolaan terhadap tanah perkebunan, perkampungan dan hutan Penghidupan mereka.

Hasil kajian berdasarkan data temuan dilapangan selama kajian ini dilakukan, konflik semakin menguat 
setelah pihak perusahaan mulai beroperasi (berproduksi), tampa terlebih dahulu menyelesaikan persoalan tumpang tindih status kepemilikan lahan tersebut. Pihak perusahaan yang merasa sudah memiliki izin dikawasan tersebut secara prontal mengalih fungsikan lahan dari hutan menjadi kebun HPHTI, proses penggarapan lahan tidak peduli dengan keberadaan kampung, kebun, kawasan perladangan masyarakat, sungai-sungai tempat mencari ikan masyarakat, perkuburan dan situs sejarah milik masyarakat. Banyak wilayah Ulayat masyarakat di Riau khususnya di Kabupaten pelalawan baralih fungsi menjadi kawasan HTI. Proses beralih fungsinya kawasan yang dianggap ulayat oleh masyarakat inilah yang mendapat perlawanan dari masyarakat. Namun karena proses awal pengalih fungsian dari kawasan yang dianggap sebagai ulayat oleh masyarakat adat di Riau ketika itu terjadi pada Era Orde Baru, dimana dominasi pemerintah terhadap masyarakat sangat kuat, masyarakat menjadi tidak berdaya.

Setelah terjadi reformasi tahun1998, Orde Baru tidak berkuasa lagi, masyarakat mulai berani menuntut dan memperjuangkan hak-hak mereka yang dirampas oleh perusahaa. Sejak itulah mulai meningkatnya intensitas dan kualitas konflik antara masyarakat dengan perusahan pemegang HPHTI, hingga saat ini proses masyarakat untuk mendapatkan hak-hak mereka atas lahan yang menurut mereka milik mereka terus terjadi.

Kasus konflik pemanfaatan lahanantara masarakat dengan perusahaan pemegang HPHTI ini sebenarnya sudah berulangkali dilakukan upaya penyelesaian, masyarakat yang protes desanya masuk dalam kawasan HPHTI milik perusahaan telah mengadukan kasus ini kepada pemerintah mulai dari pemerintahan tingkat desa hingga sampai ke pusat. Namun sejauh ini belum ada penyelesaian terkait dengan proses pengeluaran lahan milik masyarakat yang masuk dalam kawasan HPHTI perusahaan tersebut, berlarut-larutnya penyelesaian masalah ini hingga bertahun-tahun dan tidak adanya arah penyelesaian yang memuaskan juga menjadi faktor yang menyebabkan tingginya intensitas dan kualitas konflik dari waktu kewaktu hingga sampai saat ini. 


\section{Kesimpulan}

Berdeasarkan relaita diatas, maka dapat disimpulkan bahwa konflik agrarian ini terjadi karena berubahnya pola pengelolaan sumberdaya alam seperti hutan, tanah dan sungai, dari pola “subsistensi” menjadi industrialisasi disektor Kehutanan inilah yang menjadi akar konflik agrarian di provinsi Riau. Pola industrialisasi di sector kehutanan dan perkebunan yang dibuat oleh pemerintah ini, telah menyebabkan terjadinya penguasaan lahan secara meluas (monopoli) oleh segelintir orang pemilik modal (kaum korporasi) terhadap sumber daya agraris yang sebelumnya memnjadi sumber kehidupan (subsistensi) masyarakat Melayu yang berada di kampongkampung di provinsi Riau umumnya, masyarakat melayu di Kabupaten Pelalawan khususnya.

$$
\text { Hasil penelitian ini }
$$
memperlihatkan bahwa konflik agrarian antara masyarakat dengan pihak perusahaan pemegang HPHTI di kawasan Kabupaten Pelalawan antara lain adalah;

1) Tidak direalisasikan amanah hukum sesuai dengan ketentuan dari Surat Keputusan Menteri Kehutanan No. 743/Kpts-
II/1996 tanggal 25 November tahun 1996, Tentang Pemberian Hak Penguasaan Hutan Tanaman Industri Atas Areal Hutan Seluas 土299.975 На, Kepda PT. Arara Abadi.

2) Kegagalan pemerintah zaman Orde Baru dalam pengatuaran tata ruang untuk memberikan ruang kelola yang adil kepada masyarakat.

3) Ekspansi penguasaan lahan kawasan hutan untuk pengembangan industri kehutanan dan perkebunan.

4) Tidak efektifnya program pembangunan ekonomi berbasis masyarakat.

5) Tumpang tindihnya penguasaan sumber daya lahan antara masyarakat dengan perusahaan.

6) Pengabaian hak-hak hidup masyarakat dalam pengelolaan sumber daya alam oleh perusahaan.

7) Perebutan sumber daya alam oleh masyarakat.

8) Tidak terpenuhinya tuntutan konpensasi pengelolaan sumber daya oleh perusahaan terhadap masyarakat. 
9) Terbatasnya ketersediaan lahan sebagai sumber kehidupan masayarakat akibat lajunya indudtrialisasi hutan dan perkebunan. Faktor-faktor tersebut telah mengerakkan dan menjadi alasan yang mendasari terjadinya berbagai konflik antara masyarakat dengan perusahaan, masyarakat dengan masyarakat dan masyarakat dengan pemerintah.

10) Lemahnya status hukum hak kepemilikan masyarakat atas tanah ulayat.

\section{Daftar Pustaka}

Hamidy, UU 2006 Jagat Melayu Dalam Lintas Budaya di Riau. Bilik Kreatif Press.

Sobri, 2008, Konflik Dan Kekerasan Antara Masyarakat Melayu Tambusai dengan PT. Torganda Property, Tesis, Universitas Kebangsaan Malaysia, 2008.
Sobri, Indara Sapri, Tarmizi Yussa, 2011, Laporan Hasil Penelitian, Pemetaan Konflik Lahan di Kabupaten Siak, Kerjasama Penelitian Dengan Bapeda Kabupaten Siak, 2011.

Sobri, Roma Gia, Agus Nimar, Fitra Y, Kasmanto, Panca S.P, 2011, Laporan Hasil Penelitian, Potensi Konfik Sumberdaya Alam (Lahan dan Air) di Provinsi Riau, Kerjasama LP UIR Dengan Libbang Prov Riau 2012.

Surat Keputusan Mentri Kehutanan (SKMK) No. 173/Kpts-II/1986 Tanggal 6 Juni 1986 Tentang Tata Guna Hutan Kesepakatan (TGHK) di kawasan Provinsi Riau.

Surat Keputusan Menteri Kehutanan No. 743/Kpts-II/1996 tanggal 25 November tahun 1996, Tentang Pemberian Hak Penguasaan Hutan Tanaman.

Pelalawan dalam angka, BPS kabupaten pelalawan tahun 2012. 